\title{
BMJ Open Health morbidity in Brazilian prisons: a time trends study from national databases
}

\author{
Francisco Job Neto, ${ }^{1}$ Raquel Barbosa Miranda, ${ }^{2}$ Ronaldo de Almeida Coelho, ${ }^{3}$ \\ Cinthya Paiva Gonçalves, ${ }^{2}$ Eliana Zandonade, ${ }^{4}$ Angelica Espinosa Miranda ${ }^{1,5}$
}

To cite: Job Neto F, Miranda RB, Coelho RA, et al. Health morbidity in Brazilian prisons: a time trends study from national databases. BMJ Open 2019;9:e026853. doi:10.1136/ bmjopen-2018-026853

- Prepublication history for this paper is available online. To view these files, please visit the journal online (http://dx.doi. org/10.1136/bmjopen-2018026853).

Received 26 September 2018 Revised 21 January 2019 Accepted 8 March 2019

\section{Check for updates}

(c) Author(s) (or their employer(s)) 2019. Re-use permitted under CC BY-NC. No commercial re-use. See rights and permissions. Published by BMJ.

${ }^{1}$ Programa de Pós-Graduação em Doenças Infecciosas,

Universidade Federal do Espirito Santo, Vitoria, Brazil

${ }^{2}$ Programa de Pós-Graduação em Saúde Coletiva, Universidade Federal do Espirito Santo, Vitória, Brazil

${ }^{3}$ Programa de Pós-Graduação em Saúde Coletiva, Ministerio da Saude, Brasilia, Brazil

${ }^{4}$ Programa de Pós-Graduação em Saúde Coletiva, Universidade Federal do Espirito Santo, Vitoria Brazil

${ }^{5}$ Department of Social Medicine, Universidade Federal do Espirito Santo, Vitoria, Brazil

Correspondence to Dr Angelica Espinosa Miranda; espinosa@ndi.ufes.br

\section{ABSTRACT}

Objective The goal of this study was to explore the surveillance data about mandatory reporting diseases, included in the official information systems, and evaluate the historical trend analysis in prisoners in Brazil.

Design A time trends study was performed using secondary data from prisons' health units.

Setting Nationwide representative data of Brazilian prisoners obtained from 2007 to 2014 health and prison information systems database were analysed. These data are carried out by units identified as prison health facilities. Primary outcome measures Diseases diagnosis and individual data were available at the National System of Disease Notification (in Portuguese SINAN), Mortality Information System (in Portuguese SIM) and Prison Registration Systems (in Portuguese INFOPEN and GEO prisons). Analyses of the notification data performed in the SINAN at the national level. SINAN was consolidated with SIM, INFOPEN and GEO prison data.

Results A total of 23235 cases of compulsory disease notification causing morbidity were reported in prison units in Brazil; of these cases, 20003 (85.6\%) were men and 3362 (14.4\%) were women. Over time, the proportion of prisoners increased from 1.92 per 1000 inhabitants in 2007 to 2.77 per 1000 inhabitants in 2014 (rising trend). From a total of 27 states, 12 of them presented a growth in disease notifications, 14 were stable and in only one state was there a decrease in notifications. There was an increase in notifications in the country as a whole. Tuberculosis (64.4\%), dengue (9.1\%), AIDS (9.0\%) and viral hepatitis $(5.9 \%)$ were among the most frequently reported diseases during the study period.

Conclusion Despite showing stable tendencies, our results show high rates of diseases in Brazilian prisons. Prison health services should not be isolated but integrated into regional and national health and justice systems.

\section{INTRODUCTION}

The United Nations Standard Minimum Rules for the Treatment of Prisoners, known as the Nelson Mandela Rules, is a resolution adopted by the General Assembly on 17 December 2015, which recommends regarding healthcare services that: (a) The provision of healthcare for prisoners is a State responsibility. Prisoners

\section{Strengths and limitations of this study}

- This study was nationwide representative and included data about mandatory reporting disease cases that were notified in prisons units in Brazil.

- These data presented an 8-year trend analysis of notified diseases in Brazilian prisons' units.

- The use of secondary data presented some limitations but it represented the best information where there was no other source of data.

- These data were carried out from all units identified as prison health facilities in Brazil.

should enjoy the same standards of healthcare that are available in the community, and should have access to necessary healthcare services free of charge without discrimination based on their legal status; and (b) Healthcare services should be organised in close relationship with the general public health administration in a way that ensures continuity of treatment and care, including HIV, tuberculosis and other infectious diseases as well as drug dependence. ${ }^{1}$ In other words, the fact that individuals are in prison does not mean that they have reduced rights to adequate healthcare. Despite finding themselves deprived of their liberty, prisoners are still entitled to have their fundamental rights protected and the prison system must have the proper infrastructure to offer them rights such as health, education, work and other needs that in general should not be suppressed by the court's ruling. Those rights, if fulfilled, will contribute to the process of social rehabilitation. ${ }^{23}$

In Brazil, this paradox is aggravated by the adverse conditions found in prisons, such as the precariousness of physical spaces, scarcity of specialised human resources, lack of adequate healthcare and presence of structural violence practices. ${ }^{4-6}$ In the specific case of health conditions, instead of being in an environment able to safeguard physical and mental health, distress is often faced with an unhygienic and unhealthy environment. It 
facilitates the spread of communicable diseases, injuries related to violence and mental disorders. ${ }^{27}$

Communicable diseases are frequently transmitted among prisoners, and the rates of HIV, viral hepatitis and tuberculosis are much higher and complicated to deal with when compared with the general population. ${ }^{8-13}$ International and national studies also report a high prevalence of mental health problems, including substance abuse disorders, and a higher prevalence of non-communicable diseases among prisoners. ${ }^{14-17}$

Historically in Brazil, the concern regarding healthcare for prisoner populations has been low, fragmented and vertical; insofar as policies have been developed, they were limited to aspects that focused on isolated health problems and specific diseases. ${ }^{5}$ In 2014, the Brazilian Ministry of Health formulated the "National Policy for Integral Attention to the Health of Incarcerated Persons in the Prison System' in order to organise health activities and services for prisons within the scope of the national primary care model. ${ }^{4}$ This initiative extended the effective coverage of the National Health System (In Portuguese Sistema Único de Saúde [SUS]) to this particularly vulnerable population, seeking to achieve the universality of the SUS while guaranteeing the constitutional right to health with equity and integrality for prisoners.

The imprisonment organisation in Brazil is a responsibility of each federal state, producing different profiles depending of the state administration. According to the most recent report of the National Prison Monitoring Database of the National Justice Council, ${ }^{18}$ the total population of inmates in Brazil is 630092 inmates distributed in 1.423 state prisons units and four federal prisons units, $95 \%$ are men and $5 \%$ are women. Since the expansion of effective coverage of SUS for prisoners in Brazil, the epidemiological profile of this public health system, considered one of the largest in the world, has been alarming. Available data are scarce, fragmented and related to certain types of injuries, which makes difficult to understand the whole situation.

The only available information is about the mandatory reporting diseases that are in the official information systems from the Ministry of Health and the Ministry of Justice, but it is usually incomplete. The goal of this study was to explore the surveillance data about mandatory reporting diseases, included in the official information systems, and evaluate the historical trend analysis in prisoners from Brazil.

\section{METHODS}

\section{Type of study}

This study was a time trends evaluation, conducted using secondary data, from mandatory reporting disease cases from the incarcerated population in Brazil from 2007 to 2014. Diseases diagnosis and individual data were available at the National System of Disease Notification (in Portuguese SINAN), Mortality Information System (in Portuguese SIM) and Prison Registration Systems (in
Portuguese INFOPEN and GEO prisons). The units identified as prison's health facilities in the National Health System sent the information to the official information systems.

\section{Patient and public involvement}

Databases used in this study were obtained from the Ministry of Health, Ministry of Justice and the National Council of Justice. They will have access to the results of this study to be able to implement health access strategies for this population. Patients and public were not directly involved in the study.

\section{Variables}

The following variables were studied: state of origin and year of notification (the majority of prisons facilities are administrated by states), gender, age, ethnicity, schooling and notified diseases following the International Classification of Diseases, version 10. In Brazil, the notified diseases are included in the list of mandatory reporting diseases. They are selected through criteria such as magnitude, dissemination potential, social transcendence, vulnerability, availability of control measures and international commitment with eradication programmes obliging and universalizing reporting. The reports are important for the rapid control of those events that require prompt intervention. ${ }^{19}$

After performing descriptive analysis, the following indicators were proposed: (a) Proportion of prison population by state population according to the Brazilian Institute for Geography and Statistics (In Portuguese Instituto Brasileiro de Geografia e Estatistica [IBGE]) ((prison population per year/IBGE population in December per year)*1000); (b) Proportion of reported cases per state, geographical region and year ((cases reported per year/ prison population in December per year)*1000); (c) Proportion of notified diseases in relation to denominator prison population ((diseases notified per year/ prison population in December per year)*10 000).

\section{Data analysis}

To gather epidemiological data on mandatory reporting diseases in the incarcerated population, analyses of SINAN notification data at the national level were performed. SINAN data were consolidated with SIM, INFOPEN and GEO prison data. Quantitative data were analysed using the Statistical Package for the Social Sciences (SPSS, V.20.0) and Stata statistical software, V.11.2. A descriptive analysis was performed including frequency distribution for qualitative variables. Figures were prepared from the historical series and linear regression models of the variables observed throughout the study years were estimated. In addition, we presented the regression model and the value of $R^{2}$, which indicates the portion of the variability explained by the linear trend; $p$ value of F-test was also estimated, as well as the classification of the trend as stable (no trend), increasing or decreasing. The level of significance was set at $5 \%$. 


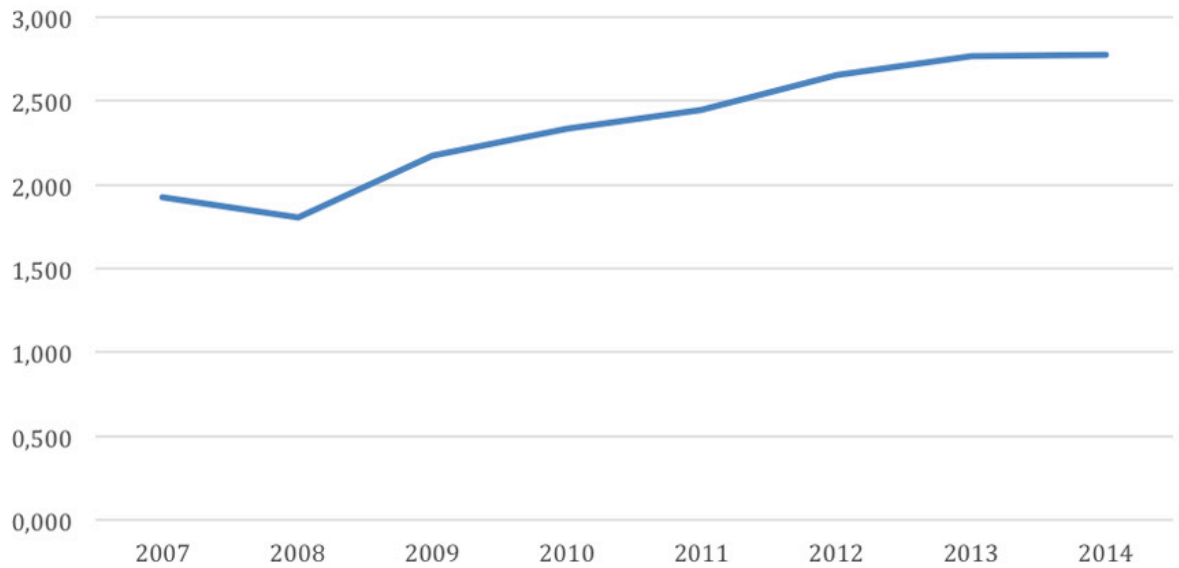

Figure 1 Historical series of the proportion of prisons' population by the annual population per 1000 people, Brazil, $2007-$ 2014.

\section{Ethical procedures}

This study was carried out with authorisation from the Ministry of Health, which released the databases without disclosing individual identification data.

\section{RESULTS}

Within the period of study, a total of 23235 cases of mandatory reporting diseases were notified in prison units in Brazil, of which 20003 (85.6\%) cases were in men and $3362(14.4 \%)$ in women. Over time, the proportion of prisoners increased from 1.92 per 1000 inhabitants in 2007 to 2.77 per 1000 inhabitants in 2014 (rising trend); data are shown in figure 1. This estimation was done using the prison population per year/IBGE population in December per year* 1000 . The prison population in Brazil was 364676 people in December 2007 and 563526 in December 2014.

The southeastern region is the geographic area with the largest number of prisoners in Brazil and that which reported the highest number of cases of disease notifications, a total of 13149 (56.3\%) cases; São Paulo state had the highest number of notifications. Subsequently, the south and northeast regions reported more cases, with $3231(13.8 \%)$ and $3213(13.8 \%)$ cases, respectively. In general, it was observed that the number of diseases notifications increased over the years, which may represent a greater access to health services. Figure 2 shows the proportions of disease reports in Brazil per year, by the prison population per 1000 inhabitants.

Table 1 presents the linear regression model with the proportion of cases reported by geographical regions and states of Brazil in the incarcerated population. The regression models were used to measure trends in the proportion of cases reported in each state and in the general total of Brazil between years 2007 and 2014. This table presents the model and the value of $\mathrm{R}^{2}$, which indicates the proportion of the variability explained by the linear trend. According to the results, it was observed that from the total of 27 states, 12 of them presented a growth in disease notifications, 10 were stable, only 1 presented a decrease in disease notifications and 4 states (one from the North and three from the Northeast Regions) did not notify any case of disease during the period. These four states present less disadvantaged economical conditions. For Brazil, in general, there was an increase in disease notifications.

Most mandatory reporting diseases are communicable diseases. Tuberculosis $(70.1 \%)$, AIDS $(7.5 \%)$, syphilis $(5.6 \%)$, dengue $(4.5 \%)$ and viral hepatitis $(3.5 \%)$ are among the most frequently reported diseases in 2014 and

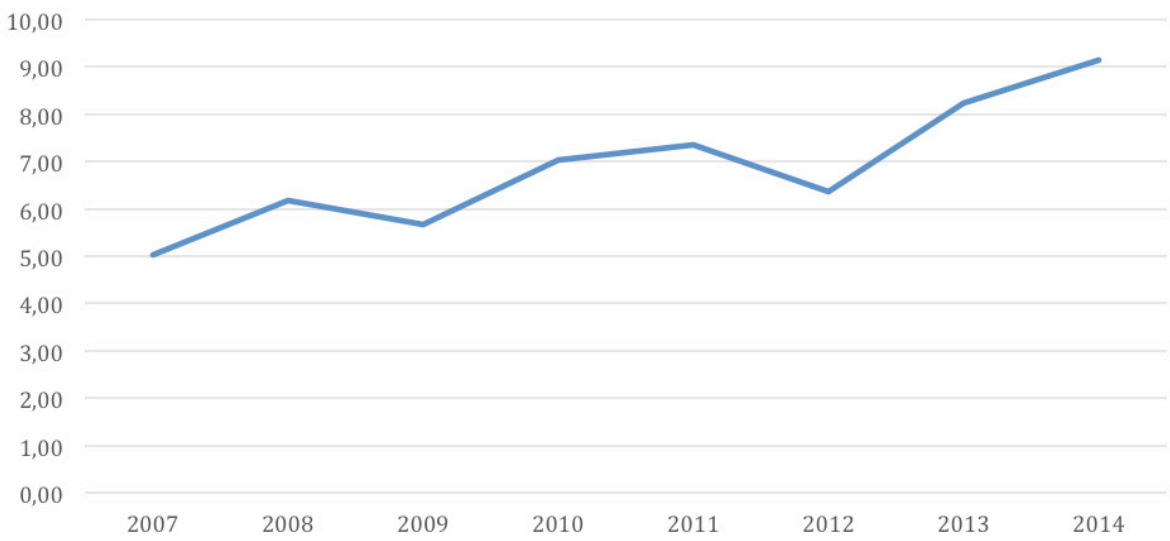

Figure 2 Trends of compulsory notification diseases reported among prisons' population in Brazil, $2007-2014$. 
Table 1 Linear regression model with the proportion of cases reported by geographical regions and states of Brazil, 20072014

\begin{tabular}{|c|c|c|c|c|c|}
\hline Region & State & Model & $\mathbf{R}^{2}$ & $P$ value & Trends \\
\hline Total & Brazil & $-6.60+1.61 \times y e a r$ & 0.798 & 0.003 & Increased \\
\hline \multirow[t]{7}{*}{ North } & Acre & $0.082+1.206 \times$ year & 0.708 & 0.009 & Increased \\
\hline & Amazonas & $-1.231+1.489 \times y e a r$ & 0.633 & 0.018 & Increased \\
\hline & Amapá & $-0.516+0.192 \times y e a r$ & 0.677 & 0.012 & Increased \\
\hline & Pará & $-0.845+0.352 x y e a r$ & 0.656 & 0.015 & Increased \\
\hline & Rondônia & 1.539+1.149×year & 0.324 & 0.082 & Stable \\
\hline & Tocantins & $-0.782-0.047 \times y$ year & 0.005 & 0.865 & Stable \\
\hline & Roraima* & - & - & - & - \\
\hline \multirow[t]{9}{*}{ Northeast } & Ceará & $0.974+1.043 \times$ year & 0.620 & 0.020 & Increased \\
\hline & Paraíba & $-1.279+0.549 \times$ year & 0.504 & 0.048 & Increased \\
\hline & Pernambuco & $-1.176+1.377 \times$ year & 0.762 & 0.003 & Increased \\
\hline & Sergipe & $-0.316+0.12 \times y e a r$ & 0.579 & 0.028 & Increased \\
\hline & Alagoas & $2.795+0.118 \times$ year & 0.012 & 0.799 & Stable \\
\hline & Bahia & 18.874-0.818xyear & 0.222 & 0.238 & Stable \\
\hline & Maranhão* & - & - & - & - \\
\hline & Piauí $^{*}$ & - & - & - & - \\
\hline & Rio Grande do Norte* & - & - & - & - \\
\hline \multirow[t]{4}{*}{ Southeast } & EspíritoSanto & $2.472+0.197 \times$ year & 0.040 & 0.634 & Stable \\
\hline & Minas Gerais & $5.410+0.165 \times$ year & 0.008 & 0.836 & Stable \\
\hline & São Paulo & 5.830-0.113xyear & 0.048 & 0.602 & Stable \\
\hline & Rio de Janeiro & 36.011-3.713xyear & 0.867 & 0.001 & Decreased \\
\hline \multirow[t]{4}{*}{ Midwest } & Distrito Federal & $-0.948+1.390 \times y e a r$ & 0.643 & 0.017 & Increased \\
\hline & MatoGrosso & $-0.750+3.413 \times y e a r$ & 0.923 & 0.001 & Increased \\
\hline & Goiás & 15.375-0.291xyear & 0.018 & 0.749 & Stable \\
\hline & MatoGrossoSul & $0.093+0.467 \times$ year & 0.177 & 0.299 & Stable \\
\hline \multirow[t]{3}{*}{ South } & Rio Grande Sul & $4.982+2.015 \times$ year & 0.541 & 0.037 & Increased \\
\hline & Santa Catarina & $-0.271+0.095 \times y e a r$ & 0.546 & 0.036 & Increased \\
\hline & Paraná & $0.075+0.008 \times y e a r$ & 0.008 & 0.838 & Stable \\
\hline
\end{tabular}

*One state from the North Region and three states from the Northeast region did not notify any case of disease during the period.

also during all the study period. It is also interesting to note the presence of antirabies vaccine $(2.1 \%)$ among the frequent ones (table 2).

Table 3 describes the results of the linear regression model to measure the trends in the proportion of cases reported between the years 2007 and 2014, according to the mandatory reporting disease. The cases notification increased in this period for syphilis and syphilis in pregnancy, male urethral discharge, Chagas disease, American cutaneous leishmaniasis and adverse effects after vaccination. Only the antirabies human vaccine demand and the exanthema lesions decreased during the study years.

\section{DISCUSSION}

It is the first study including nationwide representative health data of prisoners in Brazil. The main contribution of this study was to identify the frequency of mandatory reporting diseases in Brazilian prisons and its trends. The mandatory reporting of diseases increased in the majority of Brazilian states and main notified diseases were stable during the study period, independent of the geographical region. In general, these results can be explained by improvements in the surveillance system and because of the presence of healthcare teams inside prisons.

Tuberculosis, AIDS, dengue fever and viral hepatitis were the most frequent notified diseases in the period. These data are in agreement with other studies that show high rates of tuberculosis in Brazilian prisons. ${ }^{20} 21$ Regarding HIV, a study in the central-west region of São Paulo state found $1.6 \%$ of infection in 12 prisons. ${ }^{11} \mathrm{~A}$ literature review on HIV and tuberculosis in sub-Saharan African prisons identified data from only 24 of 


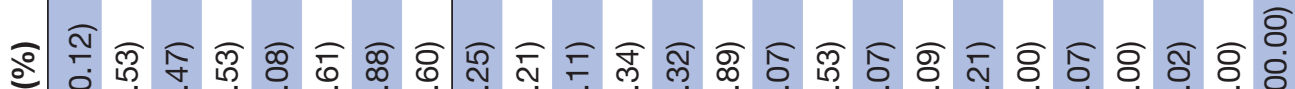

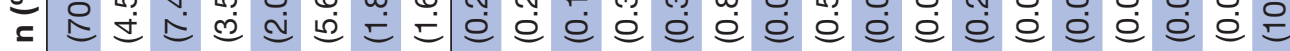

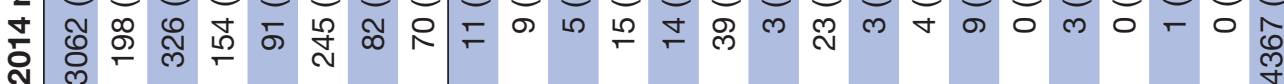

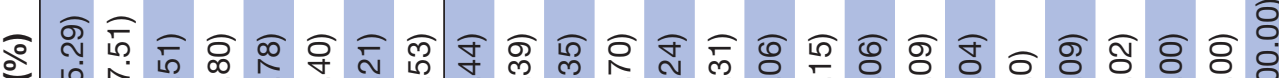
气 m

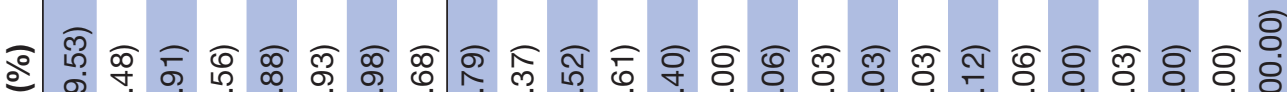
×

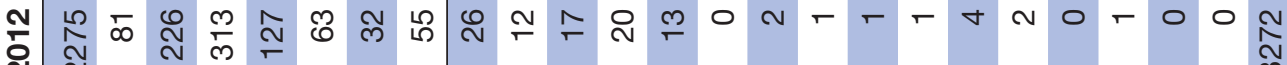
ก

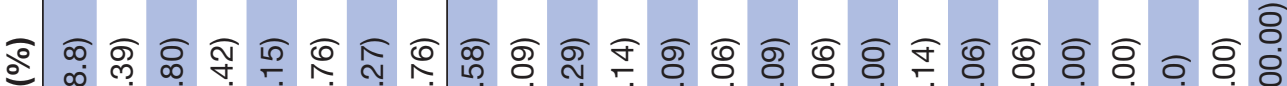
ב

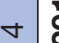

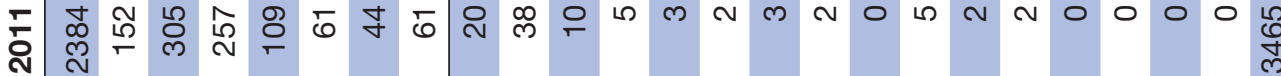

官

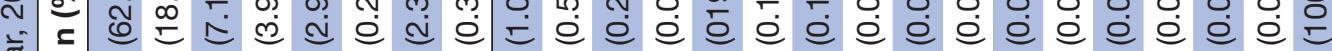
ఖ유 حे

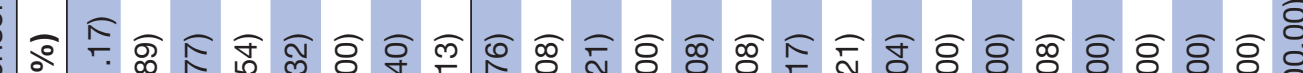
a 完

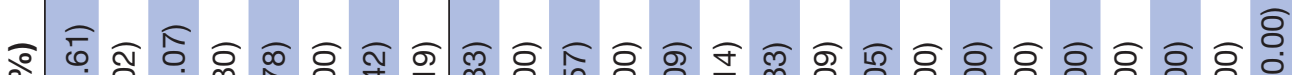
๑ li D $\frac{\pi}{\frac{\pi}{2}}$

ᄃิ) ๖

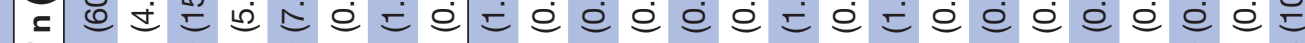
完

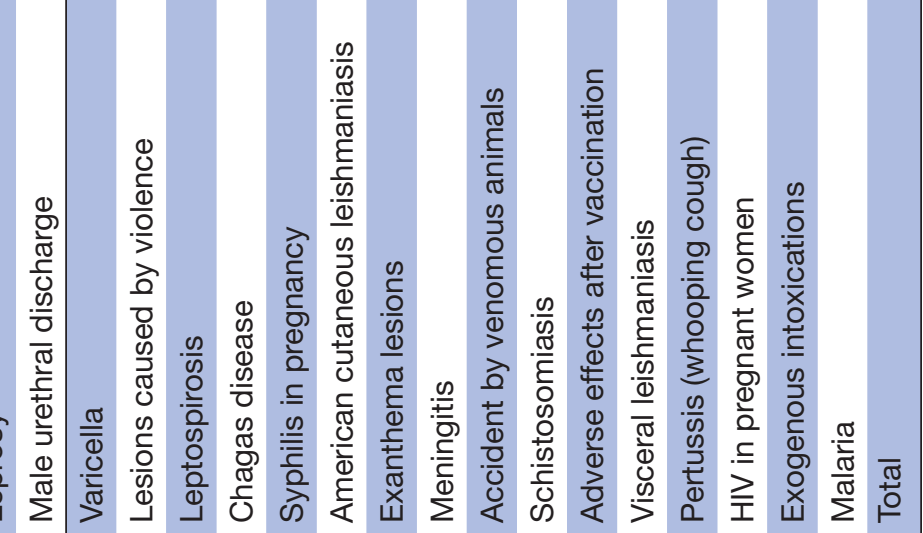


Table 3 Linear regression model of reported diseases proportion and its trends, 2007-2014

\begin{tabular}{|c|c|c|c|c|}
\hline Notified diseases & Model & $\mathbf{R}^{2}$ & $P$ value & Trends \\
\hline Syphilis & $-1.073+0.49^{*}$ year & 0.767 & 0.004 & Increased \\
\hline Male urethral discharge & $-0.182+0.176^{\star}$ year & 0.623 & 0.020 & Increased \\
\hline American cutaneous leishmaniasis & $-0.061+0.037^{\star}$ year & 0.509 & 0.047 & Increased \\
\hline Syphilis in pregnancy & $0.006+0.024^{*}$ year & 0.553 & 0.034 & Increased \\
\hline Tuberculosis & $38.098+0.538^{*}$ year & 0.032 & 0.670 & Stable \\
\hline Dengue fever & $2.861+0.579^{*}$ year & 0.078 & 0.504 & Stable \\
\hline AIDS & $7.909-0.457^{*}$ year & 0.463 & 0.063 & Stable \\
\hline Viral hepatitis & $2.831+0.180^{*}$ year & 0.079 & 0.501 & Stable \\
\hline Leprosy & $0.810+0.049^{*}$ year & 0.074 & 0.514 & Stable \\
\hline Leptospirosis & $0.245-0.007^{*}$ year & 0.029 & 0.689 & Stable \\
\hline Meningitis & $0.106-0.002^{*}$ year & 0.008 & 0.832 & Stable \\
\hline Pertussis (whooping cough) & $-0.019+0.007^{*}$ year & 0.441 & 0.072 & Stable \\
\hline Schistosomiasis & $0.189-0.024^{*}$ year & 0.175 & 0.303 & Stable \\
\hline Accident by venomous animals & $0.338-0.051^{*}$ year & 0.316 & 0.147 & Stable \\
\hline HIV in pregnant women & $-0.003+0.002^{\star}$ year & 0.249 & 0.209 & Stable \\
\hline Exogenous intoxications & $-0.004+0.001^{*}$ year & 0.333 & 0.134 & Stable \\
\hline Visceral leishmaniasis & $0.019-0.002^{*}$ year & 0.001 & 0.981 & Stable \\
\hline Malaria & $0.014-0.002^{*}$ year & 0.333 & 0.134 & Stable \\
\hline
\end{tabular}

the 49 countries in the region. In countries where data were available, they were frequently of low quality and hardly nationally representative. The prevalence of HIV infection ranged from $2.3 \%$ to $34.9 \%$, and of tuberculosis from $0.4 \%$ to $16.3 \%$ in prisoners; they nearly always had a higher prevalence of both diseases than did the non-incarcerated population in the same country. ${ }^{9} \mathrm{~A}$ wide-ranging literature review, including data published between 2005 and 2015, aimed to understand the global epidemiology of these infections in prisoners and found that $3.8 \%$ had HIV, $15.1 \%$ had hepatitis $\mathrm{C}$ virus (HCV), $4.8 \%$ had chronic hepatitis B virus (HBV) and $2.8 \%$ had active tuberculosis. The authors found higher rates in prison populations when compared with general population, mainly because of the criminalisation of drug use and the detention of people who use drugs. ${ }^{22}$

Syphilis and male urethral discharge were among the infections that presented increased notification rates in the study period. It is important to highlight that the number of syphilis cases among adults in Brazil has been consistently increasing, mainly in the vulnerable population, since $2010^{23}$. The situation is not different among prisoners in the country, who present even a higher rate of the infection. ${ }^{24}$ Prisons are known to be high-risk settings for the spread of sexually transmitted infections (STIs). A study from Ghana described high prevalence rates of HIV $(5.9 \%)$, syphilis $(16.5 \%)$ and Hepatitis B surface antigen (HBsAg) $(25.5 \%)$ among inmates. ${ }^{25}$ Also, a study from Indiana (USA) described higher rates of STIs in a cohort of individuals released from prison than in the general population, with rates in the 1 year after setting free being 2 to 7 times higher for chlamydia, 5 to 24 times higher for gonorrhoea and 19 to 32 times higher for syphilis compared with rates in the general population. Inmates, whether they enter the correctional system with STIs or contract them while in prison, become a risk to public health once they are released. ${ }^{26}$ The correctional system should be deeply committed to STIs testing and STIs reduction techniques in prisons, because the STI epidemic continues to be part of reality in several prisons. $^{27}$

Historically in Brazil, healthcare for inmates has been performed in fragmented and vertical programmes (routine immunisation, screening for tuberculosis, prevention of HIV and other sexually transmitted infections). ${ }^{67}$ There is not an infectious or chronic diseases 
prevention programme in Brazilian prisons. The country does not have a general picture of the situation and most of the published data in Brazil concerning the incarcerated population have mainly focused on HIV/AIDS, viral hepatitis and tuberculosis and are from specific states or regions. ${ }^{10-12}$ It is necessary to analyse the situation of this population from a larger perspective/scope, since other health problems are present, such as dengue, with changes in behaviour during epidemic peaks, requiring specific approaches.

Planning and executing healthcare programmes for the prison population is a global concern. Prisoners also have high levels of mental illness, chronic disease and drug use, above those of their populations of origin. ${ }^{67}$ Health problems resulting from other conditions of confinement have not been the object of healthcare actions, which would allow incarcerated people to have access to healthcare in an integral and effective way. In Brazil, these diseases are not included in the list of mandatory reporting diseases. In addition to these facts, the prisoners' conjugal visits can result in the circulation of pathogens between the prison system and the community surrounding it. ${ }^{27}$

The use of secondary data presents some limitations, that is, the use of information contained in systems such as SINAN, SIM, INFOPEN and GEO Prisons, may not reflect the magnitude of diseases among prisoners. The problem of under-reporting and inadequacy of data completeness is known; however, the information contained in these information systems can provide an initial basis for monitoring and analysing the health situation in a population that has no other data sources available. This information originates in healthcare units and data can take a long time to arrive at the Ministry of Health what can cause delayed notification. The use of multiple sources to retrieve the information of disease cases in the prison systems helps considerably to diminish the problems but does not replace the most accurate picture that could have been available if follow-up information of all exposed individuals was available.

Therefore, although currently available data may be underestimating the real magnitude of health problems in Brazilian prisons, it is the best available and can help for planning appropriate prevention and healthcare strategies addressed to this vulnerable population. Prisoners in Brazil do not have adequate access to healthcare services and neither is properly reached by the healthcare system. The use of SINAN as a monitoring tool is of great relevance for planning healthcare strategies in Brazil, and this applicability must be transferred to the prison system since it will allow reorienting attention to policies concerning the health of incarcerated people.

The increase of diseases notification among prisoners is a signal of the improvement of the healthcare for this population and can contribute for the better quality of care. These data are critical to access the quality of the health system's response and evaluate the vulnerability of the incarcerated population for accessing health care. ${ }^{6}$ The National Policy for Integral Attention to the Health of Incarcerated Persons in the Prison System in Brazil ${ }^{4}$ foresees the implementation of primary health units in prisons with more than 100 people, and the incorporation of a multiprofessional team composed at least of five professionals (physician, nurse, psychologist, social worker and dentist) and one undergraduate professional (nursing technician). In prisons with up to 100 prisoners, a health team designated by the local Municipal Health Department must perform healthcare. Access to complex levels of healthcare provided for the National Policy requires to be agreed on and defined within each state government. ${ }^{4}$ The urgency to implement a public policy of social inclusion focused on promoting human rights for this population indicates the importance of reorienting the healthcare model. The formulation of the National Health Policy in the Penitentiary System in Brazil is an initiative aimed to guarantee the constitutional rights of healthcare and access to the National Health System for prisoners with equity, integrality and universality; additionally, this policy will contribute to organising actions and health services.

Public health must be combined with criminal justice to offer medical care to prison populations, because, generally, they come from areas of society with significant levels of deficient health and social exclusion. ${ }^{27} 28$ Prisoners tend to have poorer physical, mental and social health compared with the general population. ${ }^{27} 2930$ Many prisoners have had little or no regular contact with health services before entering prison. Mental illness, drug dependence and communicable diseases are the prevailing health problems among prisoners. ${ }^{29}{ }^{31}$ Health caring for prisoners is an essential task and its main activities are critical. However, a full primary care service also includes elements of disease prevention and health promotion and should be accomplished by an interdisciplinary team with sufficient qualified personnel acting in full clinical independence. ${ }^{129}$

Measures to implement synchronised information between the criminal justice and public health organisations could generate improvements on the access to healthcare and medical information of prisoners facilitating the transition of care between the healthcare during imprisonment and after prisoners' releasing. ${ }^{3}$ It is important to ensure that medical files are transferred to healthcare services of the accepting institutions on assignment of a prisoner, as well as subject to medical confidentiality. ${ }^{1}$

\section{CONCLUSIONS}

Data regarding the health situation in prisons are important for properly developing public policies, determining priorities, guiding the planning and accomplishment of the public health system actions. Physicians and other healthcare professionals working in the prison environment should be included in strategies to reduce health disparities in this population; these professionals should receive continuous training to better understand 
the peculiarities of healthcare in prisons, the diseases notification system, the prison environment and different types of prison unities (closed, semiopen and open regimes). Prison health services should not be isolated but integrated into the regional and national health and justice systems.

Contributors FJN contributed to the study design and data collection and revised the final version of the manuscript. RBM and CPG contributed to the literature review and database revision and revised the final version of the manuscript. EZ and RdAC conducted the data analysis, contributed to the results section and revised the final version of the manuscript. AEM designed the study, supervised the design of the questionnaire plan and data collection and the writing and revised the final version of the manuscript. All authors read and approved the final manuscript.

Funding Brazilian Ministry of Health provided funding support for this study: Cooperation term \#181/2013, Process \#25000.184518/2013-41.

Competing interests None declared.

Patient consent for publication Not required.

Ethics approval This study was submitted to the Ethics Committee of the Health Sciences Center in the Federal University of Espirito Santo and it was approved under number 1.058.616/2015.

\section{Provenance and peer review Not commissioned; externally peer reviewed.}

Data sharing statement Database used in this paper belongs to the Brazilian Ministry of Health. Data can be available upon request after contacting Ronaldo Coelho at ronaldo.coelho@aids.gov.br.

Open access This is an open access article distributed in accordance with the Creative Commons Attribution Non Commercial (CC BY-NC 4.0) license, which permits others to distribute, remix, adapt, build upon this work non-commercially, and license their derivative works on different terms, provided the original work is properly cited, appropriate credit is given, any changes made indicated, and the use is non-commercial. See: http://creativecommons.org/licenses/by-nc/4.0/.

\section{REFERENCES}

1. United Nations. United Nations Standard Minimum Rules for the Treatment of Prisoners (the Nelson Mandela Rules). Adopted and proclaimed by General Assembly resolution $70 / 175$ on the Seventieth session, agenda item 106. New York: United Nations, 2016. Available: https://www.unodc.org/documents/justice-and-prisonreform/Brochure on the UN SMRs.pdf (accessed 2 Sep 2013).

2. WHO. Good governance for prison health in the 21 st century. A policy brief on the organization of prison health. Copenhagen: WHO Regional Office for Europe, 2013. Available: http://www.euro.who. int/_data/assets/pdf_file/0017/231506/Good-governance-forprison-health-in-the-21st-century.pdf

3. Rich JD, Chandler R, Williams BA, et al. How health care reform can transform the health of criminal justice-involved individuals. Health Aff 2014;33:462-7.

4. Brasil. Portaria Interministerial n. 1, de 02 de janeiro de 2014. Institui a Política Nacional de Atenção Integral à Saúde das Pessoas Privadas de Liberdade no Sistema Prisional (PNAISP) no âmbito do Sistema Único de Saúde (SUS). Diário Oficial da União, Brasília, DF, n. 2, Seção 2014;1:18-21. Available: http://bvsms.saude.gov.br/bvs/ saudelegis/gm/2014/pri0001_02_01_2014.html.

5. Fernandes LH, Alvarenga CW, Santos LL, et al. The need to improve health care in prisons. Rev Saude Publica 2014;48:275-83.

6. de Barcellos AP. Sanitation rights, public law litigation, and inequality: a case study from Brazil. Health Hum Rights 2014;16:E35-46.

7. Møller L, Stöver H, Jürgens R, Gatherer A, Nikogosian H, eds. Health in prisons: a WHO guide to the essentials in prison health. Copenhagen, Denmark: World Health Organization, Europe, 2007:7-13. Available: http://www.who.int/hiv/topics/idu/prisons/ e90174.pdf (accessed 20 Aug 2017).

8. Todrys KW, Amon JJ, Malembeka G, et al. Imprisoned and imperiled: access to HIV and TB prevention and treatment, and denial of human rights, in Zambian prisons. J Int AIDS Soc 2011;14:8.
9. Telisinghe L, Charalambous S, Topp SM, et al. HIV and tuberculosis in prisons in sub-Saharan Africa. Lancet 2016;388:1215-27.

10. Carbone AS, Paião DS, Sgarbi RV, et al. Active and latent tuberculosis in Brazilian correctional facilities: a cross-sectional study. BMC Infect Dis 2015;15:24.

11. Sgarbi RV, Carbone AS, Paião DS, et al. A Cross-Sectional Survey of HIV Testing and Prevalence in Twelve Brazilian Correctional Facilities. PLoS One 2015;10:e0139487.

12. Puga MA, Bandeira LM, Pompilio MA, et al. Prevalence and Incidence of HCV Infection among Prisoners in Central Brazil. PLOS One 2017;12:e0169195.

13. Sander G, Lines R. HIV, Hepatitis C, TB, Harm Reduction, and Persons Deprived of Liberty: What Standards Does International Human Rights Law Establish? Health Hum Rights 2016;18:171-82.

14. Fazel S, Yoon IA, Hayes AJ. Substance use disorders in prisoners: an updated systematic review and meta-regression analysis in recently incarcerated men and women. Addiction 2017;112:1725-39.

15. Rosen DL, Hammond WP, Wohl DA, et al. Disease prevalence and use of health care among a national sample of black and white male state prisoners. J Health Care Poor Underserved 2012;23:254-72.

16. Wakeman SE, Rich JD. Addiction Treatment Within U.S. Correctional Facilities: Bridging the Gap Between Current Practice and EvidenceBased Care. J Addict Dis 2015;34(2-3):220-5.

17. Mendes dos Santos M, Quintana MI, Moreira FG, et al. Drug-related disorders and the criminal and clinical background of the prison population of São Paulo State, Brazil. PLoS One 2014;9:e113066.

18. Brazil. Prisoners' National Registry. National Data Bank of Arrest Warrants - BNMP. CNJ 2018. Available: http://www.cnj.jus.br/files/ conteudo/arquivo/2018/08/57412abdb54eba909b3e1819fc4c3ef4. pdf (accessed 16 Jan 2019).

19. WHO. International health regulations. 3rd edn, 2005. Available: http://apps.who.int/iris/bitstream/handle/10665/246107/ 9789241580496-eng.pdf;jsessionid=E2AA8453D931DF8FD4E9D486 8E65F9A9? sequence $=1$ ).

20. Valença MS, Scaini JL, Abileira FS, et al. Prevalence of tuberculosis in prisons: risk factors and molecular epidemiology. Int $J$ Tuberc Lung Dis 2015;19:1182-7.

21. Sánchez A, Larouzé B. Tuberculosis control in prisons, from research to action: the Rio de Janeiro, Brazil, experience. Ciênc. saúde coletiva [Internet] 2016;21:2071-80.

22. Dolan K, Wirtz AL, Moazen B, et al. Global burden of HIV, viral hepatitis, and tuberculosis in prisoners and detainees. Lancet 2016;388:1089-102.

23. Ministério da Saúde (BR)Secretaria de Vigilância em SaúdeDepartamento de DST. Aids e Hepatites Virais. Bol Epidemiol sifilis 2017. Available: http://www.aids.gov.br/pt-br/pub/2017/ boletim-epidemiologico-de-sifilis-2017

24. Correa ME, Croda J, Coimbra Motta de Castro AR, et al. High Prevalence of Treponema pallidum Infection in Brazilian Prisoners. Am J Trop Med Hyg 2017;97:1078-84.

25. Adjei AA, Armah HB, Gbagbo F, et al. Correlates of HIV, HBV, HCV and syphilis infections among prison inmates and officers in Ghana: A national multicenter study. BMC Infect Dis 2008;8:33.

26. Wiehe SE, Barai N, Rosenman MB, et al. Test positivity for chlamydia, gonorrhea, and syphilis infection among a cohort of individuals released from jail in Marion County, Indiana. Sex Transm Dis 2015;42:30-6.

27. Binswanger IA, Redmond N, Steiner JF, et al. Health disparities and the criminal justice system: an agenda for further research and action. J Urban Health 2012;89:98-107.

28. Coyle A. Standards in prison health: the prisoner as a patient. In: Møller L, Stöver H, Jürgens R, Gatherer A, Nikogosian H, et al. eds. Health in prisons: a WHO guide to the essentials in prison health. Copenhagen, Denmark: World Health Organization, Europe, 2007:7-13. Available: http://www.who.int/hiv/topics/idu/prisons/ e90174.pdf (accessed 20 Aug 2017).

29. de Viggiani $\mathrm{N}$. Unhealthy prisons: exploring structural determinants of prison health. Sociol Health IIIn 2007;29:115-35.

30. Viggiani N. Creating a healthy prison: developing a system wide approach to public health within an English prison. Prison Service Journal 2012;202:12-19.

31. Hayton P, van den Bergh B, Moller L. Health protection in prisons: the Madrid Recommendation. Public Health 2010;124:635-6. 